\title{
Homeobox Protein Cut-Like 1
}

National Cancer Institute

\section{Source}

National Cancer Institute. Homeobox Protein Cut-Like 1. NCI Thesaurus. Code C95581.

Homeobox protein cut-like 1 (1505 aa, 164 kDa) is encoded by the human CUX1 gene.

This protein is involved in the modulation of gene transcription. 